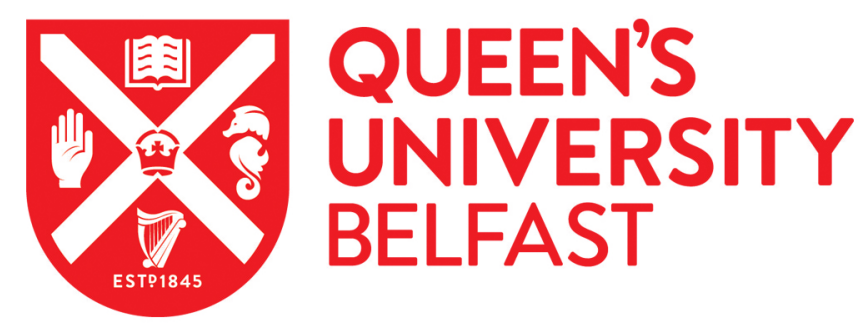

\title{
Metaphor and Matter(s) Arising: Gongorine Metaphor and the Cultivation of the Imagination
}

Collins, M. S., \& Torres, I. (2017). Metaphor and Matter(s) Arising: Gongorine Metaphor and the Cultivation of the Imagination. Bulletin of Spanish Studies: Hispanic Studies and Researches on Spain, Portugal and Latin America, XCIII(7\&8), 1129-1156. https://doi.org/10.1080/14753820.2016.1219506

Published in:

Bulletin of Spanish Studies: Hispanic Studies and Researches on Spain, Portugal and Latin America

\section{Document Version:}

Peer reviewed version

Queen's University Belfast - Research Portal:

Link to publication record in Queen's University Belfast Research Portal

\section{Publisher rights}

(C) 2016 Taylor and Francis

This is an Accepted Manuscript of an article published by Taylor \& Francis in Bulletin of Spanish Studies on 31st Aug 2016, available online: http://www.tandfonline.com/10.1080/14753820.2016.1219506

\section{General rights}

Copyright for the publications made accessible via the Queen's University Belfast Research Portal is retained by the author(s) and / or other copyright owners and it is a condition of accessing these publications that users recognise and abide by the legal requirements associated with these rights.

Take down policy

The Research Portal is Queen's institutional repository that provides access to Queen's research output. Every effort has been made to ensure that content in the Research Portal does not infringe any person's rights, or applicable UK laws. If you discover content in the Research Portal that you believe breaches copyright or violates any law, please contact openaccess@qub.ac.uk. 


\section{Metaphor and Matter(s) Arising: Gongorine Metaphor and the Cultivation of the Imagination}

\author{
MARSHA S. COLLINS \\ University of North Carolina at \\ Chapel Hill
}

\author{
$\&$ \\ ISABEL TORRES \\ Queen's University, Belfast
}

\section{Introduction}

Poetry matters. From this premise the translator David Constantine sets out to persuade his contemporary audience that "poetry springs from and belongs in the heart of society and that it does good there'. ${ }^{1}$ The efficacy of poetry, for Constantine, is down to the paradox generated by its medium; its raw material in language that is at once a shared, collective currency and a vehicle of imaginative making that marks out particulars, and relates to the real at a 'slant' angle. ${ }^{2}$ The result is a potent transaction with the world wherein connections are more profoundly felt than might be allowed for within a more conventional mimetic paradigm. At the core of Constantine's anti-Aristotelian vision for poetry, therefore, is a sense of how it thrives in vital tension between the world as we think we know itthe common, bounded, life to which we have become familiarized-and the jaggedly, unfettered spatio-temporal disjunctions, and de-familiarized meanings, that morph into being through radical imagistic stimulants of attention. Alternatively, we might say that poetry, that is intrinsically metaphorical in its dynamic movement between (at least) two worlds, wills its continued existence through uncompromising metaphorization. Yet Constantine, who recognizes that poetry's 'will to live is very great' takes little explicit account of the primary role and functions of metaphor. ${ }^{3}$ What does emerge very clearly from his 'agenda' (i.e. why poetry matters both for the individual and the society of which they are members), is how nonmimetic notions of reciprocal transport in lyric go hand in hand with antiPlatonic framing. If these counter imperatives are not at the forefront of a twenty-first century argument about poetry's place in the world, it is because the marginalization of poetry (and the arts in general) has

1 David Constantine, Poetry, The Literary Agenda (Oxford: Oxford U. P., 2013), 3.

2 Constantine, Poetry, 3.

3 Constantine, Poetry, 2. 
accorded it the ironic status of a dead metaphor. This, as we know, was not the case in the Renaissance. ${ }^{4}$ And it is precisely this anti-Aristotelian/antiPlatonic merger that matters in, and for, the poetry of Luis de Góngora; wherein (as we will argue here) a modelling of metaphor at a third remove from reality confounded his contemporaries and marked a watershed in the trajectory of Spanish poetics. As Torres has demonstrated elsewhere, the polemic that ensued had deeply resonant politico-ideological underpinnings, with Góngora's celebration of the constitutive functions of language (a critically provisional union of actuality and imagination) being condemned by those who would confine the vernacular, as vehicle, within the static strictures of more homogeneous, socio-cultural symbolic tenors. ${ }^{5}$

It is our intention in this collaborative paper to expand current thinking on Góngora's radical development of the metaphor, by focusing attention on how it operates in his work as a conduit for epistemological exploration and experiential transformation; to suggest that the cultivation of the imagination in Góngora's poetry challenges the reader to co-operate in freeing the text even from its own network of significations, even from its own carefully-crafted form, so as to reconstitute the poem's charged spaces outside itself. ${ }^{6}$ As Philip Davis reminds us, and Góngora's operations of

4 Ernesto Grassi (1902-1991) advocates a return to humanism and argues for prePlatonic notions of metaphor as a basis for the human being's understanding of the world. According to Grassi, rational epistemological paradigms are based on Platonic, fixed, objective realities, and his return to humanism (and prioritizing of metaphor as the originary act of signification and interpretation) is an attempt to restore non-rational, imaginative thought. See Ernesto Grassi, Rhetoric as Philosophy: The Humanist Tradition, trans. Timothy W. Crusius (Carbondale: Southern Illinois U. P., 1980).

5 Isabel Torres, Love Poetry in the Spanish Golden Age: Eros, Eris and Empire (Woodbridge: Tamesis, 2014), 104-21.

6 The past few years have seen a dramatic surge in Góngora scholarship, especially with the recent quadricentenary celebration of the appearance of the Polifemo and Soledades. For an excellent analysis of some of the major issues and contributions of these studies, consult Crystal Chemris, 'Highlights and Issues of the New Wave of Góngora Studies', Revista Canadiense de Estudios Hispánicos, 38:3 (2014), 419-41. The following, selected, books give some idea of the importance, and variety, of approaches encompassed by this 'new wave': Julio Baena, Quehaceres con Góngora (Newark: Juan de la Cuesta, 2012); John Beverley, Essays on the Literary Baroque in Spain and Spanish America (Woodbridge: Tamesis, 2008), 23-84; Mercedes Blanco, Góngora heroico: 'Las Soledades' y la tradición épica (Madrid: Centro de Estudios Europa Hispánica, 2012); Mercedes Blanco, Góngora o la invención de una lengua (León: Univ. de León, 2012); Rafael Bonilla Cerezo \& Paolo Tanganelli, 'Soledades' ilustradas: retrato emblemático de Góngora (Madrid: Delirio, 2013); Enrica Cancelliere, Góngora: itinerarios de la visión, trad. Rafael Bonilla \& Linda Garosi (Córdoba: Diputación Provincial, 2007); Crystal Chemris, Góngora's 'Soledades' and the Problem of Modernity (Woodbridge: Tamesis, 2008); Laura Dolfi, Luis de Góngora: cómo escribir teatro (Sevilla: Renacimiento, 2011); El poeta soledad: Góngora 1609-1615, ed. Begoña López Bueno (Zaragoza: Prensas Universitarias de Zaragoza, 2011); A Poet for All Seasons: Eight Commentaries on Góngora, ed. Oliver Noble-Wood \& Nigel Griffin (New York: Hispanic Seminary of Medieval Studies, 2013); Essays on Góngora's 'Polifemo' and 'Soledades', ed. Terence O'Reilly \& Jeremy Robbins, BSS, 90:1 (2013); Víctor Pueyo Zoco, Góngora: hacia una poética histórica (Barcelona: Montesinos, 2013); Joaquín Roses Lozano, 
metaphor confirm, unless the reader acts imaginatively as agent, the poem stays locked inside itself, imprisoned 'in Plato's cave of institutionalized unreality'. ${ }^{7}$ Ultimately we contend that metaphorization in Góngora is an inductive process that depends on the domain of the imagination to break through the limits of logical reasoning and conventional linguistic coding. Drawing on the complex interconnectedness of culture and language (meshing the diachronic and synchronic tensions of both), Góngorine metaphor extends the Grassian notion that it is in the contextual field of the imagination that we encounter our complete contingency as human beings. ${ }^{8}$ Conceptual spaces are created that are at once abstract, intellectual, and yet also rendered specific, with an imagined materiality that points towards affect; an affective sensibility that has traditionally been denied to Góngora by literary critics and poetic disciples alike. To contest these views and to suggest an appreciation of Gongorine metaphor attuned to the nurturing of the imagination, we will focus on Góngora's two major poetic compositions, the Fábula de Polifemo y Galatea and the Soledades. ${ }^{9}$ Encouraged by Les Murray's reader who keeps coming back to the same poem only to find that it still holds good, but never steady (that you cannot pitch a tent there), ${ }^{10}$ we wish now to revisit our earlier work on these texts and to develop individual approaches in ways that advocate a shared vision of Góngora's 'imaginary matters'. ${ }^{11}$ Looking forward from the exquisitely blended metaphors of Góngora's Soledades Marsha Collins will assess their significance for the Generation of '27, proposing provocative connections between Gongorine metaphor, recent theories of mind discourse and Neo-Baroque aesthetics. These connections will suggest why Góngora's metaphors continue to 'matter' for our understanding of poetry, and its multiple functions, as well as for our understanding of the human

Góngora: 'Soledades' habitadas (Málaga: Univ. de Málaga, 2007); El universo de Góngora: imágenes, textos y representaciones, ed. Joaquín Roses Lozano (Córdoba: Diputación Provincial, 2014); Góngora hoy X: 'Soledades', ed. Joaquín Roses Lozano (Córdoba: Diputación Provincial, 2010); and Torres, Love Poetry in the Spanish Golden Age, Chaps 4 \& 5.

7 See Philip Davis, Reading and the Reader, The Literary Agenda (Oxford: Oxford U. P., 2013), 122.

8 Grassi, Rhetoric as Philosophy.

9 The following editions have been used throughout: Fábula de Polifemo y Galatea in Góngora y el Polifemo, ed. Dámaso Alonso, 3 vols, 6th ed. (Madrid: Gredos, 1980), III, 13-34; Luis de Góngora, Soledades, ed. \& intro. de Robert Jammes (Madrid: Castalia, 1994).

10 Davis reflects upon Murray's essay on 'Embodiment and Incarnation' in poetry to suggest that we can have literature repeatedly, but never steadily (see 'Reading and the Reader', 120-22). First delivered as the 'Aquinas Memorial Lecture' in 1986, Murray's essay was subsequently published as: Embodiment and Incarnation. Notes on Preparing an Anthology of Australian Religious Verse, Eremos Newsletter Vol. 7, Occasional Essay Supplement (Newton: Eremos Institute, 1987).

11 Marsha S. Collins, The 'Soledades': Góngora's Masque of the Imagination (Columbia/London: Univ. of Missouri Press, 2002); Isabel Torres, The Polyphemus Complex: Rereading the Baroque Mythological Fable, BHS, 83:2 (2006). 
imagination. First, however, Isabel Torres will develop her previous work on the Polifemo, and, moving beyond questions of aemulatio, offer a reconceptualization of 'inventio' in terms of the poem's fluid relational configurations. Torres calls for a reading of the fábula in resistance to Plato's demolition of the Homeric world in the Republic, specifically the ancient text's valorization of counter-civilizing forces such as emotion, passion and a tendency towards innovation. ${ }^{12}$ The bucolic cavern of pastoral is thus transformed into a site of dark 'becoming' out of which emerges Homer's monoptic monster as a creative catalyst for the metaphorical entanglement of the human and material world.

\section{Wandering through 'Otherwhere': Figuring out Metaphor in Góngora's Fábula de Polifemo y Galatea}

The approach to metaphor that underpins the following analysis of the Polifemo is informed, in large part, by two seminal contributions to the field: Max Black's interaction theory and Paul Ricoeur's view of the imagination as a dimension of language, specifically the priority which Ricoeur gives to the reader in making metaphorical play visible. ${ }^{13}$ Also relevant is Ragnhild Tronstadt's use of metaphor theory to understand theatricality, where the relational aspect of both allows for fluid theoretical traffic. ${ }^{14}$ Recent developments in cognitive metaphor theory (CMT) have been employed very cautiously (specifically the attention to the emergent structure of figuration proposed by theories of blending), but in full cognizance of the gap between the highly contextualized nature of the present analysis and CMT's original universalising objectives. ${ }^{15}$ Most

12 Socrates, Plato's mouthpiece in the Republic (c.375 BC) calls for censorship of the existing literary canon in his imagining of an ideal polis. He identifies the types of passages that he considers to be morally corrupting and untrue, particularly passages stimulating pleasure or pain (378c-402e). What is in fact a suppression of Homer and the tragedians is made explicit through the citing of four passages from the Iliad and Odyssey to make the case, before a complete ban on Homer is called for (see Plato, The Republic, ed. \& trans G. M. A. Grube, revised by C. D. C. Reeve, 2nd ed. [Indianapolis: Hackett, 1993]).

13 Max Black, Models and Metaphors (Ithaca/London: Cornell U. P., 1962); by the same author, 'More about Metaphor', in Metaphor and Thought, ed. Andrew Ortony (Cambridge: Cambridge U. P., 1979), 19-43; Paul Ricoeur, 'Metaphor and the Main Problem of Hermeneutics', New Literary History, 6 (1974), 95-110 (especially p. 110) and, by the same author, The Rule of Metaphor: The Creation of Meaning in Language, trans. Robert Czerny with Kathleen McLaughlin \& John Costello (London/New York: Routledge, 1978).

14 Ragnhild Tronstadt, 'Could the World Become a Stage? Theatricality and Metaphorical Structures', SubStance, 31:2 (2002), 216-24.

15 What is often termed classic cognitive metaphor theory is represented by the work of the following theorists, among others: George Lakoff \& Mark Johnson, Metaphors We Live By (Chicago: Univ. of Chicago Press, 1980); Mark Johnson, The Body in the Mind: The Bodily Basis of Meaning, Imagination and Reading (Chicago: Univ. of Chicago Press, 1987); and Mark Turner, Death is the Mother of Beauty: Mind, Metaphor, Criticism (Chicago: Univ. 
pertinent, therefore, is Tamar Yacobi's recent work, which promotes attention to the textual-linguistic co-text as well as to 'the broadest historical and cultural frames'. ${ }^{16}$ The study of metaphors in context, and sensitivity to the communicative and perspectival complexity of fiction serves a double purpose: first, it draws attention to the 'rhetorical orientation of all self-conscious, communicative (as opposed to private) figure-making'; and, secondly, it connects metaphor to the communicating agent in his/her specific world or framework, and so enables it to serve broader narrative ends. ${ }^{17}$ Following this model, for instance, the Cyclops' inset song in the Polifemo would be treated as a mediated 'quotation', or, to invoke an Austinian understanding, as representation that is represented. ${ }^{18}$ Thus by moving towards a more performative understanding of the multi-functionality of metaphor-making, we can move beyond arguments over the non-mimetic in Góngora (as well as current, somewhat partial, debates over generic classification) to approach the poetry as an example of expressive culture (a concept with more currency in anthropology and performance studies than in literary analysis). As Jo Labanyi reminds us, when we begin to think more in terms of what things 'do', rather than what is represented, we can better accommodate and appreciate the potency of the emotions and the role of affect; issues that have been particularly pertinent to the reception of Góngora. ${ }^{19}$

With the exception of Luis Cernuda, who recognized the Cordovan poet as 'uno de los más apasionados poetas españoles', the Generation of '27 embraced all but the heat in Gongorine poetics. ${ }^{20}$ Despite the subsequent efforts of some isolated individuals (among them Joaquín Roses), it has been difficult to bring Gongorine metaphors in from the cold (indeed Walther Pabst declared himself 'aterrado ante la frialdad gongorina'). ${ }^{21}$ The

of Chicago Press, 1987). The development towards blending theory is demonstrated in Gilles Fauconnier \& Mark Turner, The Way We Think: Conceptual Blending and the Mind's Hidden Complexities (New York: Basic Books, 2002).

16 Tamar Yacobi, 'Metaphors in Context: The Communicative Structure of Figurative Language', in Beyond Cognitive Metaphor Theory. Perspectives on Literary Metaphor, ed.

Monika Fludernik (London: Routledge, 2013 [1st ed. 2011]), 113-34 (p. 114).

17 Yacobi, 'Metaphors in Context', 132.

18 J. L. Austin, How to Do Things with Words, ed. J. O. Urmson \& Marina Sbisá (Cambridge, MA: Harvard U. P., 1962). For a definition of 'performative utterances', see pp. $5-8$.

19 Jo Labanyi, 'Doing Things: Emotion, Affect, and Materiality', Journal of Spanish Cultural Studies, 11:3 (2010), 223-33.

20 Luis Cernuda, 'Góngora y el gongorismo', in Luis Cernuda, Obras completas, ed. Derek Harris \& Luis Maristany, 3 vols (Madrid: Siruela, 1993-1994), Prosa (2 vols), ed. Luis Maristany (1994), II, 137-47, (p. 145).

21 Joaquín Roses, 'El rayo y el águila: verdades y abstracciones en un soneto de Góngora', RILCE, Revista de Filología Hispánica, 26:1 (2008), 168-86; for Roses' view of the construction of 'frialdad' in Góngora as a critical misreading (a platform from which he seeks to demonstrate Góngora's understanding of the 'truths' of fiction), see pp. 168-70. See also W. Pabst, 'Góngoras Schöpfung in seinen Gedichten Polifemo und Soledades', Revue 
perceived dissolution of the poetic ' $\mathrm{I}$ ' (a perspective notably challenged by Antonio Carreira), aligned with identification of materiality as the essence of his poetry has validated a verdict of enigmatic objectivity. ${ }^{22}$ María Rosa Lida's assertion, 'goce de reflejar las cosas concretas: tal es la esencia poética de Góngora', was authorized famously by Jorge Guillén (1962), and has found a more recent articulation in Pedro Ruíz Pérez's Bakhtinianinspired 'voluntad de objetivación'. ${ }^{23}$ The nature and direction of the alignment that underpins these conclusions is not entirely compelling and collapses when challenged by the dense interstices of Góngora's metaphors. For these operate as a productive subject-space for readers, an intensely resonant site that, without ever relinquishing the telos of reality, activates access to what the poet Robert Graves termed 'otherwhere-ness'-a trigger for both effect and affect in the cognitive environment. ${ }^{24}$ To adapt Shakespeare, Góngora's pen produces a fluid figuring that does not so much give to 'airy nothingness' a name, but rather by re-shaping and reproducing 'las cosas concretas' to their free maximum, compels the reader to 'body forth' the 'forms of things unknown'-and, indeed, unknowable; imaginable and yet unspeakable. ${ }^{25}$ Without wishing to re-open the debate over the relationship between metaphor and visualization in Góngora, ${ }^{26}$ we would

Hispanique, LXXX (1930), 1-299 (p. 1) (translated by Nicolás Marín: La creación gongorina en los poemas 'Polifemo' y 'Soledades' [Madrid: CSIC, Patronato 'Menéndez Pelayo', Instituto 'Miguel de Cervantes', 1966]), as cited by Antonio Carreira, in 'El yo de Góngora: sus máscaras y epifanías' in Gongoremas (Barcelona: Ediciones Península, 1998), 121-59 (p. 121).

22 See Carreira 'El yo de Góngora'.

23 See respectively: María Rosa Lida, 'Review of B. Croce, Studi su poesie antiche e moderna', Revista de Filología Hispánica, II:1 (1940), 83-84; Jorge Guillén, Lenguaje y poesía (algunos casos españoles), 2nd ed. (Madrid: Alianza, 1962), 46 where he states, 'para Góngora la poesía, en todo su rigor, es un lenguaje construido como un objeto enigmático'; and, more recently, Pedro Ruíz Pérez, Entre Narciso y Proteo: lírica y escritura de Garcilaso a Góngora (Vigo: Editorial Academia del Hispanismo, 2007), 110-17 (p. 114).

24 See Robert Graves' poem 'From the Embassy' (1953), in Robert Graves, Collected Poems, 1975 (London: Cassell, 1975), 153. The poem opens with a declaration of the extraterritorial dimension which is poetry's domain and the poet's privileged mediatory role within it: 'I, an ambassador of Otherwhere / to the unfederated states of Here and Thee / Enjoy (as the phrase is) / Extra-territorial privileges'.

25 The full quotation from Shakespeare's A Midsummer Night's Dream reads: 'And as imagination bodies forth / the forms of things unknown, the poet's pen / turns them to shapes, and gives to airy nothing / a local habitation and a name' See A Midsummer Night's Dream, ed. Trevor B. Griffin (Cambridge: Cambridge U. P., 1996), 5. 1, 14-17.

26 As representative of this argument see the following: Arthur Terry, SeventeenthCentury Spanish Poetry: The Power of Artifice (Cambridge: Cambridge U. P., 1993), who acknowledges that metaphor may appeal to the senses, but works against visualization as even mental pictures are 'disintegrated [...] in the kind of verbal play induced by the images' (81); Terence O'Reilly, 'A. A. Parker and the Polifemo', in Golden-Age Essays in Commemoration of A. A. Parker, ed. Terence O'Reilly \& Jeremy Robbins, BSS, 85:6 (2008), 69-78 (pp. 72-75); and, more recently (and radically), Lucia Binotti's reading of the Polifemo as an erotic painting ('Visual Eroticism, Poetic Voyeurism: Ekphrasis and the Complexities of Patronage in Góngora's Fábula de Polifemo y Galatea', in her Cultural Capital, Language 
like to note how this process is beautifully captured in the single scope blending of Polifemo stanzas 32-34:

\section{2}

Llamáralo aunque muda, mas no sabe el nombre articular que más querría; ni lo ha visto, si bien pincel suave lo ha bosquejado ya en su fantasía. Al pie-no tanto ya, del temor, gravefía su intento y, tímida, en la umbría cama de campo y campo de batalla, fingiendo sueño al cauto garzón halla.

\section{3}

El bulto vio y, haciéndolo dormido, librada en un pie, toda sobre él pende - urbana al sueño, bárbara al mentido, retórico silencio que no entiende-.

No el ave reina, así el fragoso nido corona inmóvil, mientras no desciende — rayo con plumas - al milano pollo que la eminencia abriga de un escollo,

\section{4}

como la ninfa bella, compitiendo con el garzón dormido en cortesía, no solo para, mas el dulce estruendo del lento arroyo enmudecer querría. A pesar luego de las ramas, viendo colorido el bosquejo que ya había en su imaginación Cupido hecho con el pincel que le clavó su pecho, (249-72; emphasis added)

Here Galatea, in imaginative response mode, despite not knowing the import of Acis' performance, seems to 'understand herself' in front of Acis as image/text in progress, as new 'horizons' of experience open up before her and are coloured in. ${ }^{27}$ The literal lingers in the metaphoric doubling as the very instruments of art are at once themselves and something else, wavering between the two. Elsewhere Torres suggested that metaphorical mappings in Góngora's major poems 'extend sensuously and ingeniously as if pushing against their own materiality, testing the limits of textuality

and National Identity in Imperial Spain [Woodbridge: Tamesis, 2012], 95-125 [especially pp. 113-19]).

27 See Ricoeur, 'Metaphor and the Main Problem of Hermeneutics', 107. 
itself'; now, upon reflection, we believe that there is more than textuality tested in this process. ${ }^{28}$ The excess offered by Góngora's radical figurations gesture towards what remains absent, what transcends language. Góngora's metaphors 'deny the finite and epistemological limits of being human', but not in order 'to obscure reality with beautiful words' nor to communicate a palliative understanding of existence. ${ }^{29}$ Poetry is achieved on the very boundary of human limitation, on that 'orilla' or 'ribera' that in both the Polifemo and Soledades exposes epistemological and ontological mobility, that brings us close to the paradox of imagining what is almost inconceivable, so that limitation is the trigger for the imagination. And so in Góngora, absence/loss and human limitation are figured as a painful process of relentless Promethean renewal. The serrano speaks in these terms to the peregrino:

quédese, amigo, en tan inciertos mares,

donde, con mi hacienda, del alma se quedó la mejor prenda, cuya memoria es buitre de pesares. (Soledad I, 499-502)

From the origins of western culture, memory has been linked to poetry; and as embodied in Mnemosyne's role as mother of the Muses, it has been positioned, as Mary Carruthers observed, at the very root of human making, as 'the matrix of invention'. ${ }^{30}$ But memory is subject to imaginative reconfigurations and the 'lost houses' that Gaston Bachelard thought could be preserved in poetry, do not always come back to us whole. ${ }^{31}$ Francisco de Quevedo's return to 'la patria', for instance, poignantly captures the fragmented recollection of once solid realities, while simultaneously placing the past in front of our eyes, and allowing the flow of time 'to run the wrong way'. ${ }^{32}$ Quevedo's sonnet opens:

Miré los muros de la patria mía,

28 Torres, Love Poetry in the Spanish Golden Age, 137.

29 The quotation is taken from Peder Jothen's observations on ambiguity in aesthetics in his book Kierkegaard, Aesthetics and Selfhood: The Art of Subjectivity (Farnham/Burlington: Ashgate, 2014), 26.

30 Mary Carruthers, The Craft of Thought: Meditation, Rhetoric and the Making of Images 400-1200 (Cambridge: Cambridge U. P., 1998), 7.

31 Gaston Bachelard, The Poetics of Space, trans. Maria Jolas (Boston: Beacon Press, 1964), 56 and Paul Hetherington's perceptive article, 'The Past Ahead: Understanding Memory in Contemporary Poetry', New Writing, 9:1 (2011), 102-17 which reflects critically on Bachelard's observations (103-04).

32 The quotation in its original form refers to the Aymara language in which, according to Nicholas Evans, the 'metaphorical flow of time runs the other way'. It has been creatively applied above to temporality in Quevedo. See Nicholas Evans, Dying Words: Endangered Languages and What They Have To Tell Us (Chichester: Wiley-Blackwell, 2010), 169, as cited in Hetherington, 'The Past Ahead', 112. 
si un tiempo fuertes ya desmoronados

de la carrera de la edad cansados

por quien caduca ya su valentía. (1-4)

And it ends:

Vencida de la edad sentí mi espada, y no hallé cosa en que poner los ojos que no fuese recuerdo de la muerte. (12-14)

So, as Luis Rosales intuited in the title of an inspiring essay published in 1971, La imaginación configurante, Gongorine invention is more than a response to metaphorical sedimentation in the dominant literary domains of his day. ${ }^{33}$ The poet's engagement with Petrarchism, in particular, might well be viewed as a type of poetic manifesto, as Elizabeth Amann has suggested, but poetic distinction is also accrued through less tangible acts of reciprocal realization, involving both writer and reader in the creation of a new order of things, of new values, in short what José Ángel Valente termed, newly re-imagined 'knowledge in the making'. ${ }^{34}$ With reference throughout to the Soledades, Rosales points to the transmutation of reality effected through the components of a radically reconfigured poetic syntaxa new 'sintaxis de la realidad'-in which the material word 'alucinada por la imaginación' occupies three simultaneous planes of meaning: the real (literal); the culturally resonant (figurative) and the imaginative (the hyper-real). ${ }^{35}$ Rosales' model is equally applicable to the Polifemo, as a brief consideration of re-occurrences of the verb 'peinar' (literally, 'to comb'), in four distinct contextual and perceptual environments ( $\mathrm{vv} 8,59,162$ and 283), will demonstrate:

1 Escucha, al son de la zampona mía si ya los muros no te ven, de Huelva, peinar el viento, fatigar la selva. (6-8)

2 Negro el cabello, imitador undoso de las obscuras aguas del leteo, al viento que lo peina proceloso,

33 See Luis Rosales, 'La imaginación configurante (ensayo sobre las Soledades de don Luis de Góngora)', Cuadernos Hispanoamericanos, 257-58 (1971), 255-94.

34 See Elizabeth Amann, 'Floridas señas: Góngora and the Petrarchan Tradition', BSS, 90:6 (2013), 929-47 (p. 930), and her related article, 'The Myth of the Heliades in Góngora: Poplars, Poetics and the Petrarchan Tradition', BHS, 89:8 (2012), 831-47. José Ángel Valente claimed that every poem is 'un conocimiento haciéndose'. See his Poesía última, ed. Francisco Ribes (Madrid: Taurus, 1969), 87.

35 Rosales, 'La imaginación configurante', 272. 
vuela sin orden, pende sin aseo; (57-60)

3 Arde la juventud, y los arados peinan las tierras que surcaron antes, mal conducidos, cuando no arrastrados de tardos bueyes, cual su dueño errantes; (161-64)

4 En la rústica greña yace oculto el áspid, del intonso prado ameno, antes que del peinado jardín culto en el lascivo, regalado seno;

(281-84; emphasis added throughout)

Much has been written about the immediate metaphorical environment into which each of these utterances are embedded: (1) the poet/narrator's dedication to the Conde de Niebla as a figuring of inventive poetic creation and the inter-dependency of poet/text/reader in the construction of meaning; (2) the Cyclop's counter-blasón as symbolic of nature at its most aggressively hyperbolic - the wild and torrential beard emblematic of the free-flowing linguistic force of the poem and of Góngora's engagement with a broader evolving context that countered orthodox ideologies with an altered consciousness of language in action; (3) the disintegration of the mythical Golden Age, as well as Renaissance pastoral ideals (religio amoris) when Galatea adds the role of agricultural deity to an already compositely contaminated characterisation-agricultural activity suspended in the searing heat of unrequited desire; and finally (4) Acis the deceptive 'fallen' text whose seductive signs Galatea wilfully (mis)reads. Our purpose in this study is to draw attention to the siting of the initial metaphor in the voice of the poet/narrator, and to the centrality of the narrating voice as the mediator of all subsequent metaphorical extensions; so that the subsequent 'figuring out' depends on the interplay of (what we will term) these 'enchained emergences'. Metaphorical creativity is, therefore, a blending of the creativity that arises from the cognitive processes of extending, elaborating and combining conceptual content that is connected back to the originating domain (instigated by 'peinar el viento' and drawing from it additional knowledge structures), with what Zoltán Kövecses refers to as 'context-induced' creativity. ${ }^{36}$ Although the latter operates as a dynamic set of concentric circles, accommodating the socio-cultural setting of the

36 Within CMT Zoltán Kövecses' research is primarily concerned with context as this impacts upon variation. He has discussed the influence of different types of context on metaphorical conceptualization in several studies, including, Metaphor in Culture: Universality and Variation (New York/Cambridge: Cambridge U. P., 2005); Language, Mind, and Culture: A Practical Introduction (Oxford: Oxford U. P., 2006); and 'Metaphorical Creativity in Discourse', Insights, 3:2 (2010), 1-13. 
receiver, which implies the increased provisionality of emerging meaning, there is a stabilizing component at the core of these fluctuating perspectives - the very fact of their connection. Once it becomes clear that the poem's three protagonists (Polyphemus, Galatea and Acis) share the same conceptually blended space, readings that reduce the poem to structural and imagistic dualism, and/or balanced binaries, are inevitably threatened, as are the broader conclusions about the nature of baroque poetics that are drawn from them. Moreover, the figuration associated with all three is anchored in the voice of the narrator as primary communicating subject, and evolves from an imagined rhetorical setting, 'as if' directed to a very specific addressee, the Conde de Niebla. Once accepted, this opens up a new way of understanding the relationship between Polifemo's inset 'canto' and the poem as a whole.

Many commentators have noted and discussed the 'striking parallels' both in form and content between the Cyclops' song to Galatea and its framing stanzas. ${ }^{37}$ Despite the many, varied perspectives, there is consensus that the song operates in tension with the poem as a space through which Góngora can proclaim a new type of emulative poetics; and yet there has been an implied acceptance that the focal components of the song should be accepted as unmediated discourse. The result is acknowledgement of the rhetorical orientation of part of the song (the invocation to Galatea, for instance, as conventional, Petrarchan, metaphorical transaction), but not others-the transformation of Polifemo from cannibalistic Homeric monster into patron of shipwrecked sailors. The most recent example of this is Julio Baena's provocative reading of Galatea as a beautiful monster in whose wake lurks an even more destructive force-commerce. ${ }^{38}$ The crux of Baena's anti-capitalist argument requires the erasure of Acis' darker dimensions ('poor Acis [...] is sacrificed, annihilated') and rejection of the rhetorical function of the Cyclops' selffashioning:

Polyphemus himself is altered in the most unimaginable way. He, who was fear itself for any sailor, for the love of Galatea has rescued a shipwreck, and has given refuge in his abode to a Genoese merchant-of all people. The Genoese: the embodiment of money, of flux, of capital, of

37 For quotations, see Samuel L. Guyler, 'Góngora's 'Polifemo': The Humor of Imitation', Revista Hispánica Moderna, 37 (1972), 237-52 (p. 243). On the structural similarities between the song and the poem's dedicatory stanzas, see Anthony J. Cascardi, 'The Exit from Arcadia: Reevaluation of the Pastoral in Virgil, Garcilaso and Góngora', Journal of Hispanic Philology, 4 (1980), 119-41 and, developing upon that, Torres, The Polyphemus Complex, 64-68.

38 See Julio Baena, 'What Kind of Monster Are You, Galatea?' in Writing Monsters: Essays on Iberian and Latin American Cultures, ed. Adriana Gordillo \& Nicholas Spadaccini, Hispanic Issues On Line, 15 (2014), 26-41. 
destruction of real estate. 'Segunda tabla a un ginovés mi gruta / de su persona fue, de su hacienda' (stanza 57). ${ }^{39}$

The tendency has, therefore, been to overlook the implications of the poem's metaphorical structuring and the tension that arises when (to use Black's term) the song as 'focus' deviates from the expectations created by/in the rest of the poem as 'frame'; and when the former's gentle strains substantially modify the barbarous sounds anticipated by the latter: 'fiero canto' (20); 'bárbaro ruido' (90); 'el trueno de la voz fulminó' (359). Consequently there are two parallel communicative levels in operation, which inflect the incongruity of the 'focal' viewpoint (that of Polyphemus) with irony generated by relational dissonance. Moreover, the fact that Polyphemus' song is quoted (and marked out as such: 'irefrídlo, Piérides, os ruego! [360]), hence contextualized and controlled ('re-presented'), suggests that the figures within it also carry the additional ambiguity of subordination to the communicative aims of the quoter-in this case, the poet/narrator.

This 'perspectival montage' has often been approached, quite legitimately, in metapoetical terms, as symbolic of the oscillating modalities of early baroque lyric, which we might usefully understand in terms employed by Murray Kreiger some years ago. ${ }^{40}$ Kreiger identified in Sidney an impulse towards poetry as 'figuring forth', an anti-Platonising act of creation which he defines against pro-creative, reproductive practices: 'different from counterfeiting, as presenting is different from representing, a new face different from a flimsy disguise'. ${ }^{41}$ But there is more to Polyphemus' counterfeiting than this. At the heart of his performative instinct is not just a will to see things differently, but also to remake things differently in language. The point of departure for his song is the 'reality' of his love for Galatea, but it is an insufficient reality, and invocation to her is no more (or less) than a metaphorical habit (in accord with Christian mystery, he is the worshipper/creator of the deity). And so Polyphemus puts a different frame on it, transforming her non-productivity (her flight tramples the flowers ) into the established topos of 'generative footsteps':

39 Baena, 'What Kind of Monster Are You Galatea?', at pp. 36 and 35

40 When a're-presented' quote is framed in a different key, Yacobi identifies the operation of 'perspectival montage', defined as follows: 'Quoting thus subordinates the quote to the communicative aims of the quoter, through recontextualizing, and often also recontextualizing strategies [...] Interference by the quoter can take the form of ellipsis, addition, reordering, commentary, summary, or that of the mixture of voices and viewpoints entailed by direct, indirect, or free indirect discourse. The result is a perspectival montage between the voices and/or views apparently involved, which we as readers have to disentangle as best we can' (Metaphors in Context, 118; emphasis retained from the original).

41 Murray Krieger, 'Poetic Presence and Illusion: Renaissance Theory and the Duplicity of Metaphor', Critical Inquiry, 5:4 (1979), 597-619 (p. 599). 
'Pisa la arena, que en la arena adoro / cuantas el blanco pie conchas platea, / cuyo bello contacto puede hacerlas, / sin concebir rocío, parir perlas' (37376). But still the song fails to encompass her and certainly not as an immanent transcendent power (the hallmark of love lyric); she remains for the reader a resisting addressee, a more unsettling invasive subjectivity. Polyphemus makes of overindulgence in Petrarchan metaphors an illusionary identity for Galatea, but also for himself. As Johnson reminds us, a key task of lyric is to 'imagine personality', the yielding of the speaker's self in discourse, a 'becoming' that allows the solo lyricist to 'lie about the nature of the self'. ${ }^{42}$ Polyphemus points to the potency of such poetic transmutation in the 'sudando néctar' stanza (393-400), before extending selfhood imaginatively beyond the borders established both by the framing co-text and all previous versions of the myth. The monstrous 'truth' of his desire is not clothed, nor is it disguised in language, it is 'made'. Polyphemus imagines himself differently (he now has two eyes and projects an image of Narcissus while singing the residual poetics of Echo [417-24]), he imagines the world differently from the one he has been inflicted with (a world in which there exists the possibility of Galatea's love) and from the one which he has inflicted himself upon (in which he no longer eats sailors). There is no meaning to be 'had' in the song, rather all its metaphors merge together, and in metaphorical tension with the frame-a process of becoming that creates new 'subject spaces' and makes radical demands of the reader; even requiring us to travel in (and through) time.

The apparently anachronistic intervention of the Genoese sailor (44952 ) is, along with the narrator's invocation to the Muses, one of the more obvious signs of the song's mediated status as quotation. The reference draws an epistemic line between the song and addressees which is impassable for Galatea, but is entirely accessible to the Conde de Niebla and, through him, to contemporary readers. The breaking through of thought from the present resounds as micro messages which might be transformed in the wider sphere into alternative value systems and effects. This may well include anti-capitalism (Baena's overall argument is highly persuasive); but more because Polyphemus operates as the vehicle of a narratorial tenor and, as such, has been re-presented as the creator of a second self who has imagined himself into the role of saviour, and less because desire has effected this transformation.

When the post-structuralist philosopher, Deleuze confronted Plato, by way of engagement with Nietzsche, he focused on the Platonic distinction between the icon (the true representation of the eternal world of forms to which philosophy aspires) and the simulacrum (the false world of

42 W. R. Johnson, The Idea of Lyric: Lyric Modes in Ancient and Modern Poetry (Berkeley/Los Angeles: Univ. of California Press, 1982), at pp. 37 and 176-77. 
appearances as represented in the poetry of Homer). ${ }^{43}$ Deleuze redefined and re-valorized the simulacrum, finding in modern literature's freedom from resemblance a new protean sense of becoming against the immutability of being. The movement of the simulacrum is an aesthetic wandering, conceptualized as chaodyssey/chao-errance, paths traced without a model, and straying away from the Platonic sun. Wholesale application of Deleuze's ideas to Gongorine poetics is neither possible, nor desirable (the complete suppression of the model, for instance, is untenable), but a creative misreading points to suggestive correspondences. Straying goats, not found in any previous version of the myth, trample through the vine, and into the middle of Polyphemus' song:

Su horrenda voz, no su dolor interno, cabras aquí le interrumpieron, cuantas - vagas el pie, sacrílegas el cuernoA Baco se atrevieron en sus plantas (465-68)

The intrusion, which also exposes the lovers (471-76), extends its heretical action back metaphorically onto the horn that had announced the new progressive poetics ('Y al cuerno, al fin, la cítara suceda' [16]), and veers violently forward into new, ideologically daring and revelatory spaces. The Polifemo's metamorphic ending constitutes, in itself, a metaphor for this errant metaphorical path, tracing the materiality of experience in a Homeric 'gesture of poiein', pointing towards imaginative forming in flux, in domains that are temporally imprecise, but always with the potential to give the fullness of substance to the most liquid matter. ${ }^{44}$ Thus, through the affective interventions of Galatea ('con lágrimas la ninfa solicita' [493]) and of Doris ('con llanto pío' [503]), Acis, is transformed into 'río' and simultaneously embodied as 'yerno'. Relationality is key here, as it is throughout Góngora's errant metaphorical geography, wherein the 'pie' of the 'cabra' can blend imaginatively into the 'pasos' of the 'peregrino'.

43 Gilles Deleuze, 'Plato and the Simulacrum', in Gilles Deleuze: The Logic of Sense, ed. Constantin Boundas, trans. Mark Lester with Charles Stivale (London: Athlone, 1990), 25366. The key Platonic text in question is Sophist, 263b /264c (Sophist, ed. \& trans. Nicholas P. White [Indianapolis: Hacket, 1993]).

44 Stathis Gourgouris, 'Poiein-Political Infinitive', PMLA, 123:1 (2008), 223-28. Gorgouris defines a 'gesture of poiein' in terms of what he sees as 'essentially poetic' (referring somewhat provocatively to the transformation of disciplinarity into interdisciplinarity), by which he means: "not merely the art of making but the art of forming (thereby, in the domain of history, of transforming). [...] The oldest notion of poiein, present in Homer - while it does not arbitrate the ambiguity between forming and making-pertains primarily to working on matter, shape or form [...] It is especially interesting to consider that the root reference to creativity (démiourgia) is instrumentalist [...] From a modern point of view, then, poiein is characteristically a notion of creative action-creative and destructive' (225). 


\section{Wandering through the Imagination: Grasping the World in Góngora's Soledades and the Legacy of Gongorine Metaphor}

These 'pasos', constituted as much of richly allusive metaphors as metered, rhythmic steps or verses, remain as evocative now as in Góngora's epoch. Today, as then, when his masterpieces were circulating in manuscript form, Góngora's metaphors are the principal space of imaginative interface, the docking station between the world of the reader and that of the text, an often rather daunting portal or conduit of sorts that challenges, inspires and mirrors the activity of the mind and the imagination. Previously, Collins has studied Gongorine metaphor from a variety of hermeneutic approaches: as a display of Mannered virtuosity and source of admiratio; as a deliberately enigmatic, linguistic emblem that stimulates and challenges the mind and the imagination; as the basis for a linguistic fabric of intaglio work foregrounding metamorphosis at the micro- and macro-levels of the text; and as a process and rhetorical device that functions as a philosopher's stone to create a transformative poetics of alchemy. ${ }^{45}$ The pages that follow build on that previous scholarship to suggest in some small measure how and why the Gongorine metaphor assumed such importance for the Generation of '27, and what Gongorine metaphor might have to tell us about the current interest in the aesthetics of the Neo-Baroque and the theory of mind.

In La deshumanización del arte (1925), José Ortega y Gasset asserts that '[l]a metáfora es probablemente la potencia más fértil que el hombre posee', noting that '[s]ólo la metáfora nos facilita la evasión y crea entre las cosas reales arrecifes imaginarios, florecimiento de islas ingrávidas'. ${ }^{46}$ In 'Las dos grandes metáforas' (1924), Ortega reminds us that metaphor is both an aesthetic object and a mental process that links the world of perceived objective reality with the subjective world of the imagination and with complex, abstract conceptualization. He regards metaphor as essential to intellection and philosophical thought, defining metaphor simultaneously as an epistemological process and tool:

[...] la metáfora es un procedimiento intelectual por cuyo medio conseguimos aprehender lo que se halla más lejos de nuestra potencia conceptual. Con lo más próximo y lo que mejor dominamos, podemos alcanzar contacto mental con lo remoto y más arisco. Es la

45 Collins, The 'Soledades', 112-70.

46 José Ortega y Gasset, La deshumanización del arte, in Obras completas, 12 vols (Madrid: Alianza/Revista de Occidente, 1983), III, 351-86 (pp. 372, 373). 
metáfora un suplemento a nuestro brazo intelectivo, y representa, en lógica, la caña de pescar o el fusil. ${ }^{47}$

Note the wise and witty use of metaphor to demonstrate how metaphor functions, and also the qualities of metaphor Ortega conveys; the sudden eruption of the imaginary and the seemingly impossible in the waking or conscious mind, the unexpected surfacing of reefs and floating islands, while we believe we stand on terra firma. The philosopher communicates through the haptic and cynegetic imagery so familiar to readers of Góngora, evoking the hunt, the chase and the attempt to grasp, capture and apprehend, whether by instruments wielded by the hand, such as Ortega's rifle or fishing pole mentioned above, or Góngora's javelin, harpoons, hawks or fishing nets in the Soledades, or by the searching minds and imaginations of both authors, along with their respective writing tools.

Few poets have ever wielded metaphors of such beauty and power, or constructed them with such self-conscious artifice as Luis de Góngora. He would seem to have the etymological origins of metaphor (meta-, signifying over or across, and phérein, signifying to carry) ever present to mind in the act of composition, with metaphor's power to transfer, transform, metamorphose imaginatively as foundational to his creative praxis. Michel de Certeau associates metaphor with narrative, observing that stories 'traverse and organize places; they select and link them together; they make sentences and itineraries out of them' ${ }^{48}$ Metaphors, like narrative, then, incorporate the dynamic quality of vectors, of movement and directionality, pushing and guiding the imagination of the reader to new locales and states of awareness experienced in and by the mind.49 Unsurprisingly some of the most simple, but memorable metaphors in the Soledades possess a decidedly haptic quality that ties them to human hands, to the concepts of guidance and/or transference, and metonymically to the act of writing. The poetic voice instructs his patron, the Duke of Béjar, 'arrima a un fresno el fresno, cuyo acero, / sangre sudando, en tiempo hará breve / purpurear la nieve', that is, gently orders him to take the javelin in his hand and lean it against an ash tree as a prelude to setting aside active hunting for active contemplation, with the perspiring steel bleeding on snow mimicking the shaped ink stains of letters scratched onto parchment by the poet's quill (Dedicatoria, 13-15).50 Imaginatively Góngora signals the passage of guidance and leadership from the Duke's to

47 José Ortega y Gasset, 'Las dos grandes metáforas', in Obras completas, II, 387-400 (pp. 390, 391).

48 Michel de Certeau, The Practice of Everyday Life, trans. Steven Rendall (Berkeley: Univ. of California Press, 1988), 115.

49 Certeau, The Practice of Everyday Life, trans. Rendall, 117.

50 Quotations from the Soledades are cited by section of the poem and by verse numbers. 
his own hand and voice at the same time that the aristocratic power of the hunt is magically transferred from javelin to quill.

Throughout the Soledades, hands control, guide, transfer and metamorphose, as they move and merge with other substances. For instance, in one passage a peasant maiden juntaba el cristal líquido al humano / por el arcaduz bello de una mano / que al uno menosprecia, al otro iguala', with the hand serving as a container and conduit for the crystalline water, which matches the beauty of the appendage to that of her face, which in turn outshines the pure liquid transferred from stream to lips and/or brow (I: 244-46). Skin and water merge, but also that hand fancifully dissolves into liquid even as paradoxically it rigidifies and metamorphoses into an engineering marvel, like an aqueduct or hydraulic lift, conveying both movement, but also blending figure and ground, human and natural landscape. Elsewhere only the veins of a milkmaid's hand serve to distinguish white flesh from milk, 'blanca, hermosa mano, cuyas venas / la distinguieron de la leche apenas;' (I: 877-78), while the elegant, forceful hand of a prince exerts sufficient power through the reins to restrain the unruly majesty of his horse, in an equestrian statue brought to life, asserting reason's dominion over instinct, but also suggesting the irrational power of the imagination reined in and channelled productively from mind to hand to paper:

En sangre claro y en persona augusto, si en miembros no robusto, príncipe les sucede, abrevïada en modestia civil real grandeza. La espumosa del Betis ligereza bebió no sólo, mas la desatada majestad en sus ondas el luciente caballo, que colérico mordía el oro que süave lo enfrenaba, arrogante, y no ya por las que daba estrellas su cerúlea piel al día, sino por lo que siente de esclarecido, y aun de soberano, en la rienda que besa la alta mano de sceptro digna. (II: 809-23)

With such metaphors, Góngora seems to compose verses that anticipate the exploratory and investigatory aspects of poetry that Ortega associates with the modern age. ${ }^{51}$ The poet's Polifemo and Soledades in particular provide a rich field for contemporary, cognitive studies of the chiric functions of

51 Ortega y Gasset, 'Las dos grandes metáforas', 400. 
literary and figurative language, while Góngora simultaneously deploys kinetic metaphors that embody cognitive processes including the exercise of the mind and the imagination in the act of creation, and in the seizing, grasping and conveying of ideas. In this regard, one should keep in mind that Góngora composed poetry within a privileged circle in the context of the global and temporal crossroads of Imperial Spain, with access to some of the finest ideas, and some of the most creative artists and intellectuals of the time, living within an environment of constantly shifting, dynamically flowing ideas and creativity. Moreover, as Pablo Maurette has shown, during the sixteenth century, tactility, frequently relegated to last place in the hierarchy of senses for many centuries, underwent a vindication, a redemption of sorts, in which touch was integrated with the other senses, collaborating together to generate new notions of self, knowledge and world. Maurette links this transition with an 'epistemological shift from authority-based evidence to first-hand experience', along with a reevaluation of the importance of the body, and the breakdown of the opposition between soul and body in which the soul rejects the body. ${ }^{52}$ This new appreciation for tactility and corporeality, he maintains, also can be associated with 'a reaction against long-established dualisms, an exaltation of curiosity, and a fascination with the eccentric, the paradoxical, and the ambiguous'. ${ }^{3}$ While these are qualities he rightly identifies with the shifting intellectual sensibilities of the sixteenth and seventeenth centuries in general, these are also qualities readily identifiable with, and embodied within, Góngora's poetry and Gongorine metaphor in particular, which we have characterized as 'metaphor at a third remove' through which poet and reader create 'a new order of things, new values, [...] a newly re-imagined "knowledge in the making"'. Góngora's metaphors constitute a type of crossroads in which are inscribed new, dynamic models for reading, perceiving and understanding, and for breaking down conventional boundaries between reader and writer, material and spiritual, body and soul, subject and object, to construct a new world in which intellection and imagination collaborate.

Significantly this slippage, and breaking of boundaries, which leads almost inevitably to the constant movement of the errant, ever-questing, ever-discovering Gongorine metaphor, also looks backward to classical antiquity, and reveals the poet's profound engagement with Ovid's Metamorphoses. The Roman masterpiece was written by an exile from court, who could be described as a pilgrim cast out under mysterious circumstances, whose memories of Rome, apparent in the poems' verses, haunt him at every turn. At the same time, Gongorine metaphor looks

52 Pablo Maurette, 'Plato's Hermaphrodite and a Vindication of the Sense of Touch in the Sixteenth Century', Renaissance Quarterly, 68:3 (2015), 872-98 (pp. 873, 874).

53 Maurette, 'Plato's Hermaphrodite', 895. 
back to Ovid's work, not only for inspiration and source material from the plethora of mythological micro-narratives of transformation embedded in a lengthy poem of hybrid genre, which Góngora clearly emulates in the Soledades overall, but also for tropes that capture the essence of Pythagoras' philosophy as voiced in Book 15 of Ovid's great poem, emphasizing the transformative interconnectedness of nature's elements and all living things, including humans, their history and artifice. This philosophical viewpoint links thought and poetic creation with natural processes of transformation, not just spectacular examples of often hybrid, monstrous metamorphosis, embracing even cosmogonic and historical events in Ovid's magnificent textual web. Góngora probably in part envisaged his Soledades as a modern counterpart to the Metamorphoses, and also as a Spanish rival that surpasses the Latin poem with revelations and understanding awakened, renewed and replenished with each reading of the poem, generating new knowledge through a complex web of conceits and shifting contexts and perceptual environments, as seen earlier in this essay in the poet's use of the verb peinar in the Polifemo.

Recently Brian Boyd has pointed out the special power that metaphor exercises to appeal to the cognitive preferences of certain audiences, as a strategy that compels readers' attention and as a rhetorical device that creates an 'aura of suggestion', opening a text up and radiating outward, that is, inscribing imaginative vectors into the world of the poem. ${ }^{54}$ The Gongorine metaphor mobilizes this power so successfully that the poet at times virtually anatomizes the metaphor at work stimulating the imagination. For example, a conceit from Soledad II illustrates Góngora's skill in putting several systems of referentiality at play simultaneously:

Hermana de Faetón, verde el cabello, les ofrece el que, joven ya gallardo, de flexüosas mimbres garbín pardo tosco le ha encordonado, pero bello. Lo más liso trepó, lo más sublime venció su agilidad, y artificiosa tejió en sus ramas inconstantes nidos donde celosa arrulla y ronca gime la ave lasciva de la cipria diosa. Mástiles coronó menos crecidos, gavia no tan capaz: estraño todo,

54 Brian Boyd states: 'Just as a live metaphor in poetry creates an aura of suggestion rather than a pinpoint illumination, meaning in story more open-ended than fable tends to radiate out' (On the Origin of Stories: Evolution, Cognition, and Fiction [Cambridge, MA: The Belknap Press of Harvard U. P., 2009], 372-73). See Boyd (392-98) on the integral relationship between art's power to compel attention and its impact on humans, in which he notes the power of metaphor, among other elements and strategies, to draw attention. 
el designio, la fábrica y el modo. (II: 263-74)

At the simplest level, the reader can discern at least three different contexts of signification at play in the conceit to describe this ever-shifting dovecote cleverly woven into the tree: (1) the myth of Phaethon's sisters, who, grieving for their brother's death, were transformed into poplars; (2) the association of the dove with Venus, love, youth and desire; and (3) the heights climbed by the old fisherman years ago in his youth to weave the wonder-inducing net cage, likened to a swaying crow's nest up on a tall ship's mast. Readers instantly combine these different systems, which at first glance might seem mutually exclusive, to envisage a younger version of the old man, when he was perhaps a sailor, and was definitely a more agile youth susceptible to love's call. The metaphor blends the present with the past evoked by memory, merges the elements of earth, water and air, and continues the poem's emphasis on verticality and Icarian rises and falls. The conceit thus models what cognitive scientists Mark Turner and Gilles Fauconnier refer to as a space of conceptual blending or integration in which metaphoric mapping moves separate input spaces, that is, mental spaces created separately, into an overlapping area of combined, multiple spaces, networks and/or systems of signification that are no longer mutually exclusive. ${ }^{55}$ Moreover, this conceit or area of combined blending merges with other, larger areas of conceptual blending in the Soledades, such as images that merge art and nature, images that foreground the function of memory, images of the life cycle and life's continuity, images pertaining to love and multiple perspectives on love, the mise en abyme images that mirror the Gongorine conceit with its sinuous, dynamic, formless form, and reference to imaginative process, a network of vessels and containers like the river of Soledad I (197-211) and the wall-less, knotty labyrinth of the fishing net of Soledad II (73-80), and more.

As we know, the members of the Generation of '27 lavished praise upon Góngora in large part for his masterful, imaginative creation of metaphors, a poetic process and product which they emulated and reinvented in myriad forms of highly personal expression. In his famous lecture 'La imagen poética de don Luis de Góngora' (1925-1926), for instance, Federico García Lorca refers to the author of the Soledades as 'el padre de la lírica moderna', asserting 'inventa por la primera vez en el castellano un nuevo método para cazar y plasmar las metáforas y piensa sin decirlo que la eternidad de un poema depende de la calidad y el trabazón de sus

55 Fauconnier \& Turner, The Way We Think, 279-84. Turner and Fauconnier tend to characterize the human process of conceptual integration as metaphorical, at times involving several systems of metaphorical cross-mapping. 
imágenes'. ${ }^{56}$ According to García Lorca, Góngora invents a new way of creating metaphors arising from hunting (that familiar concept) and then expressing them by giving form to the formless, cazar $y$ plasmar, but he also invents a new poetic language and type of poem grounded in a network of interlinked images and systems of imagery, el trabazón de sus imágenes. Similar sentiments are voiced by other members of the Generation of '27, such as Pedro Salinas, who likens Gongorine poetic praxis to a process of alchemy, in which the author extracts precious metals from coarse and common materials. ${ }^{57}$ While clearly these modern poets foreground Gongorine metaphor for its magical properties of transference and transmutation, they also, by varying degrees explicitly, or implicitly or intuitively, focus with fascination on the Gongorine process of creating conceits, resorting to figurative language to encapsulate what their predecessor did to generate and craft metaphors. As Ortega points out in La deshumanización del arte, this is, after all, the Generation that produces cerebral or intellectual art forms that inspire cognitive delays and meditation, responses similar to those demanded of an ideal reader of the Soledades and its network of conceits. In that regard, we also must remind ourselves of the new ideas circulating in the early twentieth century that reframed radically the ways in which some people were thinking of time, space, and subjectivity, under the influence of Freud, Bergson, Einstein and others. Yet along these lines, certain ideas associated with metaphor cultivation emerge over and over through the years, and, in varying contexts, eventually become strongly identified with Góngora's poetry, and nestle on the poet's shoulders as a crowning mantle of achievement in metaphor fabrication, to wit: (1) the primacy of visualization techniques in image production, which appears in Longinus' concept of phantasia as generator of admiratio, and then later in García Lorca, who designates sight the ruling sense in metaphor production and the enactment of metaphoric process; (2) the concept of metamorphosis, which appears in Ovid and elsewhere in classical antiquity, then throughout the Ovidian revival and re-creation in Early Modern Europe, and then later in García Lorca, Salinas, Guillén, Dámaso Alonso, and inherently in avant-garde movements such as surrealism; (3) the concept of sudden perspectival shifts, which appears in Longinus' notion of the sublime and Gracián's notions of ingenio y agudeza, exemplified to perfection by Góngora, and which later appears as an integral part of avant-garde art forms, and is mentioned by Ortega, Lorca, and encapsulated by Dámaso Alonso in that Gongorine formula $A$, si no $B$; (4) the self-referential trope of the

56 Federico García Lorca, 'La imagen poética de don Luis de Góngora', in Conferencias, intro., ed. \& notas de Christopher Maurer, 2 vols (Madrid: Alianza, 1984), I, 85-125 (pp. 96, 97).

57 Pedro Salinas, 'La exaltación de la realidad: Luis de Góngora', in La realidad y el poeta, intro., ed. de Soledad Salinas de Marichal (Barcelona: Ariel, 1976), 155-70 (p. 166). 
net/network, which was a commonplace in classical poetry, is certainly present in Ovid, resurfaces in Góngora's poetry and that of other Early Modern European writers, and then emerges yet again in the poetry of the Generation of '27.58 Significantly, similar qualities emerge in recent theory of mind discourse focusing on the human imagination. Gregory Currie and Ian Ravenscroft, for instance, note that the exercise of the imagination requires a capacity for perspectival shifting, and the creative imagination demands sudden leaps of the mind that defy conventional expectations. Imaginative perception, they affirm, involves substitution and transference with the generation of visual imagery growing out of actual visual experience. In fact, Currie and Ravenscroft state, sensory perceptions are the key to imaginary praxis, along with beliefs and desires, which enable the imaginer or artist to project or imagine other possibilities, which may then be transferred into works of art. They go so far as to link the imagination with humans' ability to see into the minds of others, which suggests the pivotal role art can or could play in creating empathy and building networks of people across traditional differences and boundaries, leading into the realm of affect. ${ }^{59}$

Despite the primacy thus attributed to the visual in metaphor production and conceptualization well into the twentieth century in the West, in the actual poetic praxis of Góngora and his Spanish legatees, while the eyes or ears of the imagination may provide the initial attentionarousing, sensory triggers in establishing that link between reader, poetic metaphors, and the imaginative world of the text, sights and/or sounds do lead to a more intimate, and more corporeal or tactile grasping or apprehension of that world, and its potential ideas and affects. The reader engages in actualizing metaphor, which generates the space in which the imagination can move and conceptualize. This space contains the concepts and qualities readily identified with the cold intellectualism often

58 The work was originally ascribed to Longinus, although the actual author remains unknown. On Longinus and Góngora, see Collins, The 'Soledades', 124-35; on the primacy of sight in metaphor production see Longinus, 'On Sublimity', in Classical Literary Criticism, ed. D. A. Russell \& M. Winterbottom, trans. D. A. Russell (Oxford: Oxford U. P., 1989), 143-87 (pp. 159-62), and García Lorca, 'La imagen', 99-101. On unexpected perspectival and conceptual shifts, in artful words, thoughts, and actions, see Baltasar Gracián, Agudeza y arte de ingenio, ed., intro. \& notas de Eviaristo Correa Calderón, 2 vols (Madrid: Castalia, 1969), I, 144-51, 188-96, 247-54; II, 141-45. On the Gongorine structure 'A, si no B', see Dámaso Alonso, 'La simetría bilateral', in Estudios y ensayos gongorinos, 2nd ed (Madrid: Gredos, 1960), 117-73. On the metapoetic net, see: Collins, The 'Soledades', 132-34; Marsha S. Collins, 'Mastering the Maze in Góngora's Soledades', Caliope, 8:1 (2002), 87-102; and Thomas G. Rosenmeyer, The Green Cabinet: Theocritus and the European Pastoral Lyric (Berkeley: Univ. of California Press, 1969), 177-78.

59 Gregory Currie \& Ian Ravenscroft, Recreative Minds: Imagination in Philosophy and Psychology (Oxford: Clarendon Press, 2002), 7-13, 192-97. 
attributed to the poetry of Góngora and the Generation of '27, but also contains or leads to affect, a feature less frequently recognized. In the space of the imagination actualized in engagement with Gongorine metaphors, then, readers move beyond oppositional barriers of mind and body, intellect and emotions to reach a new realm of the imagination, in which mind and affect dynamically interact to create a new and different world of possibilities often actualized as a sort of visionary experience.

A brief analysis of two famous poems, written respectively by Jorge Guillén and Vicente Aleixandre, who figure prominently among Góngora's galaxy of poetic legatees, will show how this metaphorical, Gongorine space of the imagination unfolds. In Guillén's 'Naturaleza viva', a cubist aesthetic constitutes an integral part of the context of signification of Guillén's poem. The title alone invites readers to consider these verses as both alternative and complement, $A$ si no $B$, to the still life painting of Cézanne, Picasso, Braque and others:

Naturaleza viva

¡Tablero de la mesa Que, tan exactamente

Raso nivel, mantiene

Resuelto en una idea

Su plano: puro, sabio,

Mental para los ojos

Mentales! Un aplomo,

Mientras, requiere al tacto,

Que palpa y reconoce

Cómo el plano gravita

Con pesadumbre rica

De leña, tronco, bosque

De nogal. ¡El nogal

Confiado a sus nudos

$\mathrm{Y}$ vetas, a su mucho

Tiempo de potestad

Reconcentrada en este

Vigor inmóvil, hecho

Materia de tablero

Siempre, siempre silvestre! (Cántico: Fe de vida) ${ }^{60}$

60 Jorge Guillén, Cántico (1931), in Aire nuestro, 4 vols (Barcelona: Barral, 1977), I, 50. 
Cubism, of course, frequently foregrounds underlying geometric forms, and challenges viewers, sometimes playfully, to view the subject matter from different perspectives, often simultaneously, in an imagined, conceptually blended space. Guillén signals readers that a similar game is afoot here, for instead of a naturaleza muerta, the poet shifts perspective with the words naturaleza viva, asking readers to see the table top, a typical, domestic element in cubist still lifes but generally not unaccompanied, as nature that still pulses with life. Note that the visual, in the form of perception by the eyes of the mind, opens this perhaps unexpected world for contemplation, and enables the subjective consciousness to employ the more intimate and sensual sense of touch to grasp or apprehend the essential wild, sylvan nature materia [...] silvestre, concentrated, reconcentrada, in the board, and captured through sensory hunting and seizing by means of an active mind and imagination. Guillén builds a series of such apprehensions into a network of correspondences that leads readers imaginatively from the relatively small, intimate, domestic space of examination of a flat wooden surface, out into the wide, open space of nature, and into a forest to contemplate stately walnut trees, and examine the majestic power of the particular tree whose life force, su mucho tiempo de potestad, has been distilled into its still living quintessence, but in different form, whether as a table top, or through Guillén's metaphorical alchemy, as a poem, which celebrates the life all around us for those who have eyes to see it.

For all of the verses' emphasis on the visual, however, and the clear relationship of the imagery with cubism, famous for its often cerebral, witty tenor, the visual collaborates with the haptic in 'Naturaleza viva' to guide the reader not only into optical observation of nature's life force in distilled form, but also into the realm of affect, into joy and exaltation before the wildness of nature. Emotive, exclamatory sentences open and close the poem, marked with Guillén's typically detailed and precise punctuation, and the physical contact between the hand and the walnut wood, with its nudos and vetas, so similar to the nudos and venas of the human hand, contributes to the impression of two living entities, each responding with warm reciprocity to the palpitating, vital energy of the other. That moment of physical contact with the wood in fact establishes the connection between the human subject and the natural world, and widens the space of the imagination even further to encompass what lies beyond the immediate confines of the interior, domestic space, and to glory in that personal connection to nature. ${ }^{61}$

61 For more criticism related to this poem, consult: C. Christopher Soufas, Conflict of Light and Wind: The Spanish Generation of 1927 (Middletown: Wesleyan U. P., 1989), 4143; Wifredo de Ràfols, "Del cubismo a las circunstancias. El motivo de la mesa en dos momentos de la trayectoria poética de Jorge Guillén: "Naturaleza viva" y "A nivel" , BHS, 
Aleixandre's Circuito, grounded in surrealist aesthetics, explicitly celebrates network imagery of circuitry and circulation, derived from an alternate, imaginary world in which rhythmic pulsation and circular movement are an outward manifestation that eventually merges across rational borders and boundaries with the pulsing circulatory system of the human speaker and with the inexorable flux, like the tides, of the speaker's unnamed desires. As in Guillén's poem, Aleixandre's Gongorine imagery liberates and generates a world of imagination, a space in which sensory experiences, a process of abstract intellection, and a variety of intensely powerful emotions blend together conceptually, modelling this experience for readers and allowing them into the world that the material, the intellectual, and the affective collaborate to create:

\section{Circuito}

Nostalgia de la mar.

Sirenas de la mar que por las playas quedan de noche cuando el mar se marcha. Llanto, llanto, dureza de la luna, insensible a las flechas desnudas.

Quiero tu amor, amor, sirenas vírgenes que ensartan en sus dedos las gargantas, que bordean el mundo con sus besos, secos al sol que borra labios húmedos.

Yo no quiero la sangre ni su espejo, ignoro si la tierra es verde o roja, si la roca ha flotado sobre el agua. Por mis venas no nombres, no agonía, sino cabellos núbiles circulan. (Espadas como labios) ${ }^{62}$

Once again visualization provides entrée into the poem's imaginary world, asking readers to conjure a scene of sirens or mermaids beached and abandoned at night by the sea's receding tide. Every aspect of the intimate dialogue the poetic voice undertakes with these mythic figures bespeaks a rejection of dryness, bright or defining light, 'secos al sol que borra labios húmedos', harsh lines and plane surfaces, 'su espejo', 'la roca', specific names and detailed suffering, as in the worn-out romantic poetic discourse of the past, 'no nombres', 'no agonía', juxtaposed with an embrace of

82:1 (2005), 45-58; and Miguel A. Olmos, 'Jorge Guillén, lector de Góngora', Signa, 18 (2009), 365-90.

62 Vicente Aleixandre, in Espadas como labios (1932), in Obras completas, pról.. de Carlos Bousoño (Madrid: Aguilar, 1968), 241-318 (p. 252). 
wetness and dissolution, a celebration of biomorphic forms that blend together in the conceptual space of a subjective consciousness in which the sirenas are at once a projection of and what is immersed within an inner world, a jarring perspectival overlay, in which desires that resist the fixity of language float and circulate like the hair of the nubile mermaids. Here, too, tactility plays an important role in establishing intimacy-'dedos', 'besos', 'venas', 'circulan' - in which the pulsing liquids of water (nature) and blood (humans) mirror and affirm each other's similarities as lifegiving forces, in essence dissolving barriers between the two. Note that the poet accesses and identifies this world with the night-the time of obscurity or blurred or uncertain vision, also the time of dreams, of mystical experience, and the time in which the irrational reigns supreme. Aleixandre uses the pulsing, floating, geometric form of the circle to enable artistic cohesion of the surrealist verses: 'ensartan [...] las gargantas', 'bordean el mundo', 'Por mis venas [...] circulan'. ${ }^{3}$ Readers of the Soledades might be reminded of the water world Góngora constructs in his poem, as well as his marked fascination with natural cycles, rhythms, and networks, including the circulation of water, of his sudden perspectival shifts, and of his use of repeated geometric forms as a conceptual unifier that links images across rational borders, as in Soledad II (701-05) in which a column's spherical capital reflects back the rays of light emanating from the rising sun.

The Gongorine metaphor so cherished by the poets of the Generation of '27 proves especially illuminating for our understanding of current approaches to the Neo-Baroque, and of the ongoing resurgence of interest in the Baroque. For Góngora's elaborate conceits provide a fruitful way out of what at times resembles an endlessly bifurcating path that juxtaposes centre and periphery, West and non-West, matter and spirit, reason and affect. Gongorine metaphor enacts, models and celebrates paradox, defying linear, rational thought in freeing the imagination to leap, and move about, in a skewed, decentred, and unpredictable manner, to move (true to the etymological origins of metaphor) across the impasses that some suppose are inscribed into the dynamics and structures of paradox and contradiction. Góngora's metaphors trigger readers, the ones who engage actively with them, to unleash the powers of the human mind and imagination in an unceasing, dynamic flow of images and ideas that activate the imaginative process that blends and bridges matter and spirit,

63 For more criticism related to this poem consult: C. B. Morris, Surrealism and Spain, 1920-1936 (Cambridge: Cambridge U. P., 1972), 58-63, 127, 38; Soufas, Conflict of Light and Wind, 111-13; Antonio Pérez Lasheras, 'Espadas como labios, forma y ritmo de una cosmovisión', Revista de Literatura, 49:97 (1987), 115-41 (pp. 119-27); and Anthony L. Geist, " "Esas fronteras deshechas": Sexuality, Textuality, and Ideology in Vicente Aleixandre's Espadas como labios', in The Surrealist Adventure in Spain, ed. C. B. Morris (Ottawa: Dovehouse, 1991), 181-90. 
concept and affect. As Lois Parkinson Zamora and Monika Kaup have stated:

Despite the skepticism of the Baroque about the efficacy of the senses, despite its preoccupation with deceptive appearances and recurring themes of illusion and disillusionment-despite these undercurrents and also because of them, the Baroque celebrates sensory opulence, corporeal and material abundance, kinetic exuberance. Baroque forms invite participation; only then do sight and insight, thought and feeling, theory and practice converge as the Neo-Baroque requires. ${ }^{64}$

This invitation extended to the reader to participate in the conceptual bridging and blending that only the imagination can perform has undoubtedly lent Gongorine metaphor its exceptional, enduring poetic power and compelling aesthetic and philosophical appeal.

In his seminal essay 'El barroco y el neobarroco' (1972), Severo Sarduy characterizes the Neo-Baroque as a world of hybridity, proliferation, transgression, and overabundance, as a revolutionary world that defies limitation or categorization. Gilles Deleuze describes contemporary aesthetics similarly, as a new Baroque of infinite twists, turns, and folds, in essence portraying the arts and the world as continuously in a dynamic process of changing, in perpetual metamorphosis that defies rigidity, and fixed classifications and categorizations. ${ }^{65}$ Just as Góngora's metaphors map the mind and the imagination at work and play, then so, too, do they demonstrate and lay a foundation for this interactive, open-ended, ever inventive, imaginative aesthetics identified with the Neo-Baroque. 'Pasos de un peregrino son errante [...]': as Góngora's silvas curve and swerve across the page tracing metaphors, they track the folding and unfolding footprints of the human imagination, and offer inspiring insight into metaphor as enactive, transformative process that challenges and bridges human thought, spirit, and feeling, a powerful legacy that still speaks to us in a compelling and meaningful way across the centuries.*

64 Lois Parkinson Zamora \& Monika Kaup, 'Baroque, New World Baroque, Neobaroque: Categories and Concepts', in Baroque New Worlds: Representation, Transculturation, Counterconquest, ed. Lois Parkinson Zamora \& Monika Kaup (Durham, NC: Duke U. P., 2010), 1-35 (pp. 26-27).

65 Severo Sarduy, 'El barroco y el neobarroco', in Obra completa, ed. Gustavo Guerrero \& François Wahl, con intro. de Gustavo Guerrero, 2 vols (Madrid: ALLCA XX, 1999), II, 1385-404; Gilles Deleuze, The Fold: Leibniz and the Baroque, foreword \& trans. by Tom Conley (Minneapolis, Univ. of Minnesota Press, 1993), 3-13, 121-26.

* Disclosure Statement: No potential conflict of interest was reported by the authors. 